\title{
Impact of Regional Fiscal Capacity and Regional Economic Growth on Improving the Welfare of the Community in Regencies/Cities in Kalimantan
}

\author{
Muzdalifah Muzdalifah ${ }^{1}$ \\ \{Muzdalifah.feb@ulm.ac.id ${ }^{1}$ \} \\ Economic Development, Faculty of Economics and Business, Lambung Mangkurat University, \\ Banjarmasin, Indonesia ${ }^{1}$
}

\begin{abstract}
The Purpose in this research to understand what the impact of fiscal capacity and regional economic growth are on improving the welfare of the community in districts / cities in Kalimantan. The methods use in research are Klassen typology and Panel Data Regression using SPSS and Eviews software. The research describe Scarter Plot IKFD and Growth, There are only 6 Regencies/ Cities that are in quadrant 1, the rest are mostly in quadrant 3 and 4. Scarter Plot IKFD and IPM, There are only 11 Regencies/Cities that are in quadrant 1 , the rest are mostly in quadrant 3 and 4 . The best model adalah Fixed effect model with the Chow and Hausman test, the simultaneously all independent variables (IKFD and Growth) affect the dependent variable (IPM) and Partially it is known that only the IKFD variable has a significant effect on the level of welfare in the Regency / City with a negative relationship, The coefficient of determination (R2) is $88.83 \%$, which means that the proportion of variance in the predictable welfare variable from the IKFD variable and growth is 88.83 percent, the rest is explained by other variables outside the model.
\end{abstract}

Keywords: IKFD, growth economic, social welfare

\section{Introduction}

The dependence of local governments on transfer funds is a common condition experienced by almost all city districts in Indonesia. This dependence has consequences for weak regional independence to carry out various activities and programs that must be carried out to develop the region. Through the Regional Fiscal Capacity Index (IKFD) we get an overview of the financial capacity of each region which is reflected in the general APBD revenue (excluding special allocation funds, emergency funds, old loan funds, and other revenues whose use is limited to finance certain expenses) to finance government duties after deducting personnel spending and linked to the number of poor people.

The role of government in the view of [1] that government spending is divided into 2 streams, namely as government expenditure (G) and also investment (I) government, Keynes divides aggregate demand into two types of expenditure, namely consumption expenditure by households and investment by entrepreneurs. In its development, aggregate expenditure can be divided into four components of household consumption, corporate investment, government spending, and exports. Government spending is an activity related to the function of the government to regulate economic activity but can also affect the level of aggregate spending in 
the economy, due to market imperfections, keyness (Neo-classical) to New Keynes believes that government policy is still needed to stabilize the economy.

Market failure requires the government to intervene in regulating the economy so that people's welfare can be achieved optimally, as for the role of government in the economy according to [2] through 3 functions, namely allocation, distribution and stabilization.

In relation to the implementation of regional autonomy, the role of government in the economy in its implementation refers to 2 approaches according to [3], namely based on the views of Musgrave and Neo Classics, where according to Musgrave's view the existence of the public sector is to carry out the main functions of government which are determined by the existence of externalities and the level of preference it causes the implementation of main tasks that must be centralized such as the stability function, and those that must be decentralized such as the allocation and distribution function, according to the Neo Classical view with the political economy approach assuming that local people have relatively homogeneous preferences (like individuals), so that local government choices closer to or more in line with individual choices than choices made by the central government.

According to [4] there are three main missions for the implementation of regional autonomy and fiscal decentralization, in an effort to empower local governments, namely: (a) improve the quality and quantity of public services and community welfare, (b) creating efficiency and effectiveness of regional resource management, and (c) empowering the community to participate in development.

Based on the Fiscal Capacity index, regions are grouped into 4 (four) categories of Fiscal Capacity as follows: (a) regions whose Fiscal Capacity index is more than or equal to 2 (index $=2$ ) are regions that fall into the very high Fiscal Capacity category; (b) areas whose Fiscal Capacity index is between more than or equal to 1 to less than $2(1<$ index $<2$ are areas that fall into the high Fiscal Capacity category; (c) an area whose Fiscal Capacity index is between more than 0.5 to less than $1(0.5<$ index $<1)$ is an area that is included in the moderate Fiscal Capacity category; and (d) areas whose Fiscal Capacity index is between more than or equal to less than 0.5 (index $<0.5$ ) are regions that are included in the low Fiscal Capacity category.

The average condition of the district/city IKFD in Kalimantan is fluctuating and shows a downward trend, especially in North Kalimantan, where there is a very large decline, this means that there is a decrease in fiscal capacity in each district / city in each province in Kalimantan. The size of the IKFD in each province in Kalimantan also shows an uneven distribution, especially in years 1 to 5 . When viewed based on the IKFD category from 56 Regencies/ Cities in Kalimantan, it is known that the average IKFD figure is $30.35 \%$ in the very high and high categories, $15.26 \%$ in the medium category and $12.5 \%$ in the low category.

Social welfare in the view of welfare economic theory according to Pigou (1960) is a part of social welfare that can be linked directly or indirectly to the measurement of money. Meanwhile, the notion of social welfare according to Whithaker and Federico (1997) is a nation's system of benefits and services to help society to obtain social, economic, and educational and health needs which are important for the survival of the community. A person who has a lack of ability may have low welfare, a lack of ability, which means that he is less able to achieve certain functions so he is less prosperous [5].

The ideal condition regarding government intervention does not always cause government intervention in the economy to increase people's welfare, because the government can also fail because it does not carry out its functions efficiently, this inefficiency is caused by several things according to Hyman (1993) in [6], namely; Imperfect information; Limited oversight of private party reactions; Limited oversight of bureaucrat behavior; Barriers to the political process; There are large transaction costs. 
The economic growth of districts / cities in Kalimantan is known that the average growth of districts / cities in Kalimantan in 2016 has decreased in North Kalimantan, East Kalimantan and Central Kalimantan, while the other 2 provinces in Kalimantan Island experienced a slight increase which occurred in South Kalimantan and West Kalimantan. From the beginning of observations from 2012 to 2019, the magnitude of the economic growth rate in Kalimantan fluctuates and after experiencing a significant contraction in most provinces, starting in 2017 it has shown recovery and in 2019 the economic conditions in all Provinces in Kalimantan are relatively good even though some have experienced a tendency decreased as in the provinces of South Kalimantan, Central Kalimantan and West Kalimantan.

The HDI condition in 5 Provinces on the island of Kalimantan shows the same trend, namely increasing, there is a fairly high disparity of HDI between provinces, East Kalimantan Province is in the top position and West Kalimantan is the lowest, while in the other three provinces the amount is relatively the same and is between the twoThe dependence of regions on transfer funds that occurred in many regencies/cities in Indonesia also occurred in Kalimantan, independence in regional fiscal low capacity, weakened the region's ability amidst the global uncertainty, the decline in commodity prices on the global market and this pandemic reduced the regional economy on the island of Kalimantan, very intrested to understand what are the impact of fiscal capacity and regional economic growth on improving the welfare of the community in Regencies/Cities in Kalimantan.

\section{Method}

This study is obtaining secondary data from BPS and Indonesia Database for Policy and Economic Research. The collected data are; Regional Fiscal Capacity Index, Growth GRDP, Human Development Index

Data in research include 5 provinces with 56 Regencies/Cities in Kalimantan from 2012 to 2019 (7 years). The method to measure the impacts is panel data regression. Regional Fiscal Capacity Index (IKFD) as dependent variable, Growth GDRP (Economic Growth) as dependent variable, Human Development Index (IPM) as independent variable. The model options are Pooled Least Squares (PLS), Fixed Effect Model (FEM), and Random Effect Model (REM). Panel Data Analysis uses the Multiple Regression model, where the formulation is as follows:

$$
\mathrm{IPM}_{\mathrm{it}}=\beta_{0}+\beta_{1} \mathrm{IKFD}_{\text {it }}+\beta_{2} \text { Growth }_{\text {it }}+\varepsilon_{1 \mathrm{it}}
$$

Determination of the model chosen using the Chow and Hausman test. F test was performed to determine the effect of independent variables simultaneously on the dependent variable and $t$ test to determine the effect of the variable partially.

\section{Results and Discussion}

\subsection{Scarter Plot IKFD and Growth}


There are only 6 Regencies/ Cities that are in quadrant 1, the rest are mostly in quadrant 3 and 4 Malinau dan Nunukan in Kalimantan Utara, Murung Raya, Lamandau dan Sukamara in Kalimantan Tengah, Berau in Kalimantan Timur. Figure 1 shows the scarter plot IKFD and growth.

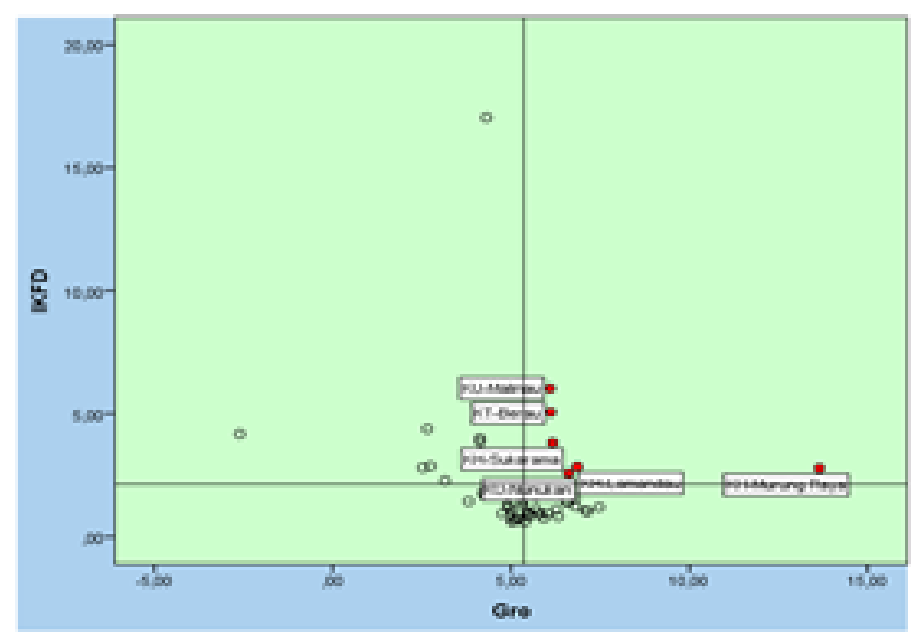

Fig. 1. Scarter Plot IKFD and Growth

\subsection{Scarter Plot IKFD and HDI}

There are only 11 Regencies/Cities that are in quadrant 1 , the rest are mostly in quadrant 3 and 4, 9 in Kalimantan Timur; Samarinda, Balikpapan, Kabupaten Paser, Penajam Paser Utara, Kutai Kertanegara, Kutai Barat, Kutai Timur, Berau, and Bontang. 2 in Kalimantan Utara; Malinau and Bulungan. Figure 2 shows scarter plot IKFD and HDI.

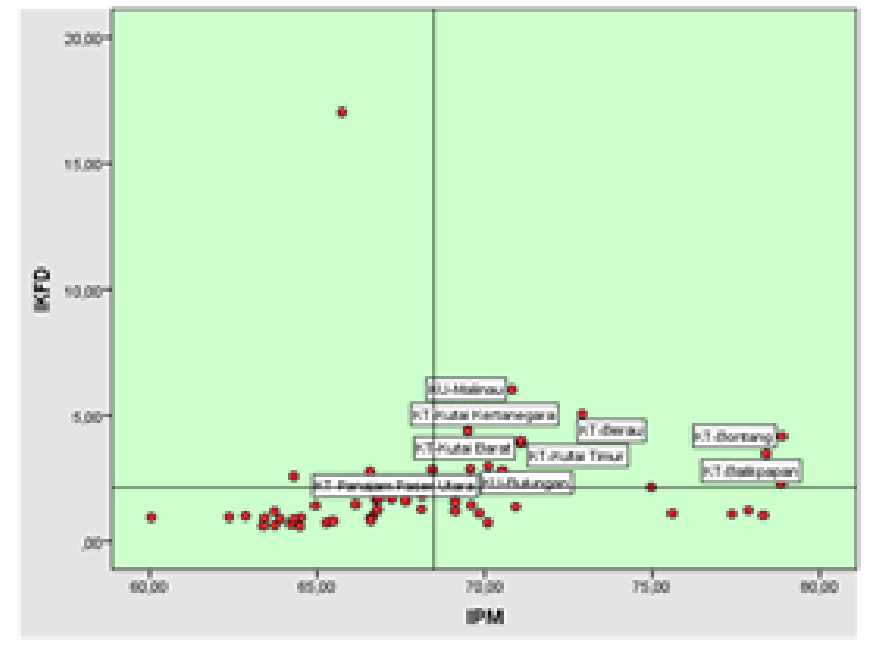

Fig. 2. Scarter Plot IKFD and HDI 


\subsection{Scarter Plot Growth and HDI}

There are only 11 regencies/cities that are in quadrant 1 , the rest are spread out in quadrant 2, 3 and 4. 5 in Kalimantan Tengah; Palangka Raya, Barito Timur, Kotawaringin Timur, Kotawaringin Barat, dan Gunung Mas, 2 in Kalimantan Selatan; Banjarmasin dan Banjarbaru, 1 in Kalimantan Barat; Singkawang, 2 in Kalimantan Tengah Utara; Malinau dan Tarakan, 1 in Kalimantan Timur yaitu Berau.

The best model adalah Fixed effect model, the chow test is known that the F Cross-section with Prob 0.0000 rejects Ho, which means that the FEM model is better than PLS, Hausman test Cross-section random with Prob 0.0684 accept Ho, which means FEM is better than REM.

\subsection{Impacts on Social Welfare}

Goodness of fit test $\mathrm{F}$ test or regression coefficient test simultaneously shows that the statistical Prob F value is 0.0000 , which means that simultaneously all independent variables (IKFD and Growth) affect the dependent variable (IPM). The coefficient of determination (R2) is $88.83 \%$, which means that the proportion of variance in the predictable welfare variable from the IKFD variable and growth is 88.83 percent, the rest is explained by other variables outside the model. Partially it is known that only the IKFD variable has a significant effect on the level of welfare in the Regency/City with a negative relationship with a coefficient of -0.252 . Table 1 shows the Result of Econometric Estimation Fixed Effect Model (FEM).

Table 1. The Result of Econometric Estimation Fixed Effect Model (FEM).

\begin{tabular}{lrrr}
\hline \multicolumn{1}{c}{ Variable } & Coefficient & \multicolumn{1}{c}{ Std Error } & \multicolumn{1}{c}{ Prob } \\
\hline C & 69,390 & 0,286 & 0.000 \\
IKFD $_{\text {it }}$ & $-0,252$ & 0,037 & $0.000^{*}$ \\
Growth $_{\text {it-1 }}$ & $-0,073$ & 0.051 & $0.154^{*}$ \\
R-squared & 0.8883 & & \\
Prob.F-statistic & 0,000000 & & \\
\hline Note: * significant at alpha 1\% & &
\end{tabular}

The findings in this study are in line with empirical study of [7]-[10] conclude that government spending does not have a significant effect and can even negatively affect the welfare of society.

\subsection{Relationship between IKFD and Sosial Welfare}

Out of 56 regencies / cities in Kalimantan, the average IKFD, 60.65 percent of regencies / cities are in the very high and high categories, only 26.78 percent in the medium category and 12.5 percent in the low category. The findings of this study support the theoretical study that high fiscal capacity will have an impact on increased welfare, this means that regencies/cities with high IKFD have an impact on high social welfare even though the confidence level is $88.83 \%$ and if there is something that is not in line, it means that it is influenced by variables outside the model.

According to [11] each city / district government faces various fundamental problems that demand financing. One of the problems that will give rise to the potential for a very large 
increase in financing is the increase in program needs as a result of the rapidly increasing population. This condition will require local government funding for spending on pensions, social security, health and other facilities. In addition, in the next five years, local government needs for spending on school-age residents will still be quite large. Thus, the city / regency government is faced with the potential problem of increasing the need for financing amid conditions of large fiscal dependence. This certainly demands a fiscal transfer policy from the central government to the regions that is able to solve this problem.

The high gap of the IKFD in regions that generally have a wealth of natural resources compared to IKFD in areas that have no or only a few natural resources, so even though the percentage of the category is Very High, it is comparable to the Regency / City which is in the category. High, but in absolute terms the gap is quite large.

On the other hand, because most of the natural resources that are owned by many regencies / cities on the island of Kalimantan are in the form of coal commodity which is a mainstay export commodity which is very vulnerable to price fluctuations, so that the IKFD of districts / cities on the island of Kalimantan tends to fluctuate, because it is very dependent on global conditions. . This also affects district / municipal budget allocations due to an element of uncertenty.

In line with the development needs issued by the regions, one of the important efforts made by the regions is understanding perceptions and increasing operational capacity. Therefore, every development sector requires funding to finance every detail of programs and activities that have been implemented or will be implemented so that national development plans and regional development plans can be in line and have the same common thread [12][13].

\subsection{Partial Magnitude}

The effect of the variable partially 45.45 percent of regencies/cities show a coefficient that has a positive impact, meaning that partially when the IKFD increases it will have an impact on increasing social welfare. 54.54 percent of regencies/cities show a coefficient that has a negative impact, meaning that partially when the IKFD increases it has an impact on reducing social welfare. Table 2 show the partial magnitude.

Tabel 2. Partial Magnitude 


\begin{tabular}{|c|c|c|c|c|c|}
\hline No & regencies/cites & Magrifude $\mid+1$ & No & regencies/cites & Magrifude $\mathrm{H}$ \\
\hline 1 & KT-Beras & 5.249481 & 1 & KH-Barito Selatan & -0.560502 \\
\hline 2 & KT-Kutai Kertenegara & 3.575807 & 2 & KH-Barito LTara & -0.924568 \\
\hline 3 & KT-Kutai Barat & 1.284813 & 3 & KHJK@фuas & -1.893 .913 \\
\hline 4 & KT-Kutai Timur & 3012301 & 4 & KHKoringan & -1727.263 \\
\hline 5 & KT-Paier & 2030493 & 5 & KH-Senyan & -3.684 .524 \\
\hline 6 & KT-8alikpapan & 10.19523 & 6 & KH-Pulang Pisau & -2.390 .282 \\
\hline 7 & KT-Bontong & 10.34630 & 7 & KH-Munung Ragya & -1660.929 \\
\hline 8 & KT-Samarinda & 10.26245 & 8 & KB-Benckayare & -3.535 .479 \\
\hline 9 & KT-Panciom Poxer Utara & 1.114201 & 9 & K.BLandak & -4.619 .520 \\
\hline 10 & KH-Kotawaringin Barat & 2373771 & 10 & KB-Koques HLlu & -4997.814 \\
\hline 11 & Kh-Kotowa'ngin Timu & 0.581238 & 11 & KB-Kelapona & -4.169 .824 \\
\hline 12 & KH-Polonglea fiapa & 9.716545 & 12 & KB-Mempomah & -5.458047 \\
\hline 13 & KH-SLkarama & 0.594911 & 13 & KB-Sambas & -4.358 .685 \\
\hline 14 & KH-Lamandou & 0.273892 & 14 & KB-sangagu & -5.348 .166 \\
\hline 15 & KH-Gunng Mas & 0.624527 & 15 & K.B_Sinteng & -4.473 .288 \\
\hline 16 & KH-Bailo Tmur & 1.148287 & 16 & KB-Sekadau & -6.322 .974 \\
\hline 17 & KB-Porntanak & 8.650075 & 17 & KB-Meland & -5.121 .743 \\
\hline 18 & KB-Singkamong & 1.306459 & 18 & KB-Kapong utara & -8.697 .253 \\
\hline 19 & KS-Jabaliong & 0.867025 & 19 & KB-Kubu Raya & -3.254 .271 \\
\hline 20 & $\mathrm{KS}$-Baniarbanu & 9.291823 & 20 & KS-Banjar & -1.906 .434 \\
\hline 21 & KS-Banjomasin & 6947555 & 21 & KS-Barto Kucla & -4895.064 \\
\hline$n 2$ & Ku-Moinas & 3.200942 & 22 & KS-HSS & -2140.135 \\
\hline 23 & Ku-Bulungan & 1.570705 & 29 & KS-HST & -2.163 .699 \\
\hline 24 & KU-Tano Tolung & 0.645180 & 24 & KS-HSU & -5.879041 \\
\hline \multirow[t]{6}{*}{25} & KU-Jarakan & 6.487062 & 25 & KS-Kotobanu & -1.750 .206 \\
\hline & & & 26 & KS-Tanah Lout & -1.432 .648 \\
\hline & & & 27 & KS-Tapin & -0.590247 \\
\hline & & & 29 & KS-Balangan & -2.616 .002 \\
\hline & & & 29 & kS-Tanah Bumbu & -0.479481 \\
\hline & & & 30 & KU-Ptunikon & -4.293 .206 \\
\hline
\end{tabular}

\section{Conclusion}

Regencies/cities with positive magnitude (having SDA or not) indicate that the Regional Government has succeeded in making budget allocations that are oriented towards social welfare and vice versa. Economic growth has no significant effect on social welfare and the magnitude is negative, this anomaly generally occurs in developing countries, where this economic growth is not equal distribution (gaps occur) so that it does not have a significant impact on social welfare.

\section{References}

[1] Keynes and J. Maynard, The General Theory of Employment, Interest and Money. 1936.

[2] R. Musgrave and P. Musgrave, Public Finance in Theory and Practice, 5th ed. Singapura: McGrawHill Book Co, 1989.

[3] R. Simanjuntak, "Otonomi Daerah dan Desentralisasi Fiskal, Sumbangan Pemikiran FE-UI pada Reformasi dan Pemulihan Ekonomi," 1998.

[4] Mardiasmo, Otonomi dan Manajemen Keuangan Daerah. Andi. Yogyakarta. Yogyakarta: Andi, 2002.

[5] S. Hadi, "PERAN DESENTRALISASI FISKAL TERHADAP KINERJA EKONOMI DI KABUPATEN/KOTA PROVINSI JAWA TENGAH,” J. Ekon. Pembang., vol. 10, No.1, pp. 103124, 2009.

[6] M. Khusaini, Ekonomi Publik Desentralisasi Fiskal dan Pembangunan Daerah. Malang, 2006.

[7] B. C. Olopade and D. Olopade, "The Impact of Goverment Expenditure on Economic Growth and Development Countries : Nigeria as a Case Study," EcoMod, 2010.

[8] E. Iheanacho, "The Contribution of Government Expenditure on Economic Growth of Nigeria Disaggregated Approach,” Int. J. Econ. Manag. Sci., vol. 5, no. 5, 2016. 
[9] I. Sumardjoko, “Analisis Efisiensi Belanja Langsung Melalui Penguatan Belanja Modal Daerah dan Implikasinya Terhadap Pertumbuhan Ekonomi Regional,” Defis, vol. 1, pp. 71-90, 2017.

[10] I. F. Okombi, "The Impact of Goverment Expenditure on Economic Growth in Congo," IJER, vol. 9, no. 1 , pp. 19-36, 2018.

[11] [B. Brodjonegoro, “The Indonesian Decentralization After Law Revision: Toward a Better Future ?," econ.hit online, 2005.

[12] E. J. Blakey, Blakely, Edward J, 1994. Planning Local Economic Development Theory and Practice, 2th ed. Sage Publication Inc California, 1994.

[13] R. Boadway, "Lessons from Industrialised Countries, in Indonesia's Public Sector in The Twenty First Century: Planning For 2020 and Beyond," in Preparing The Public Sector for 2020:, 1997. 